\title{
HEGEMONI MEDIA SOSIAL: AKUN GOSIP INSTAGRAM @LAMBE_TURAH
}

\section{SOCIAL MEDIA HEGEMONY: GOSIP INSTAGRAM ACCOUNT @LAMBE_TURAH}

\author{
Christiany Juditha \\ Puslitbang Aplikasi Informatika dan Informasi Komunikasi Publik \\ Kementerian Komunikasi dan Informatika RI \\ Jl. Medan Merdeka Barat No. 9 Telepon: 021-3800418 Jakarta 10110 \\ Email: christiany.juditha@kominfo.go.id \\ (Diterima: 06-02-2018; Direvisi: 27-04-2018; Disetujui terbit: 06-06-2018)
}

\begin{abstract}
Abstrak
Berita terbaru tentang para selebritis tidak hanya dapat diperoleh dari tayangan infotainment di televisi saja, tapi juga melalui akun gosip di media sosial. Salah satu diantaranya di akun Instagram @lambe_turah. Akun gosip ini dari sisi bisnis sangat menguntungkan karena juga menjadi media promosi berbagai produk. Namun sisi lain, juga menguak privasi orang tanpa memikirkan implikasi dan reaksi masyarakat menjadi masalah tersendiri. Hingga di sini hegemoni (kekuatan) media sosial mendominasi fenomena ini.Tujuan kajian ini adalah untuk mendapatkan gambaran tentang hegemoni ekonomi, politik dan budaya media sosial pada akun gosip @lambe_turah. Metode penelitian menggunakan studi literatur. Hasil penelitian menyimpulkan bahwa kekuatan ekonomi@lambe_turah dapat dilihat dari pesan-pesan yang terdistribusi secara bersamaan, dan dapat diterima oleh followers-nya yang terdiri dari berbagai kelas khalayak. Dengan jumlah pengikut jutaan, @lambe_turah masuk dalam jajaran selebgram endorsement yang menghasilkan keuntungan ekonomi. Hegemoni politik @ lambe_turah dapat dilihat dengan bebasnya mereka memposting berita apa saja tentang para selebriti baik sisi positif maupun negatif. Kekuasaan yang tanpa batas inilah menjadikan@lambe_turah beberapa kali memiliki masalah dengan sejumlah artis apalagi jika berita tersebut negatif. Sedangkan hegemoni budaya dalam @lambe_turah secara simetris tergambar dari banyaknya postingan yang di-like dan dikomentari menandakan bahwa perhatian netizen sangat tinggi. Akun@lambe_turah juga memiliki pengaruh dalam pembentukan opini publik.
\end{abstract}

Kata kunci: hegemoni, media sosial, akun gosip, instagram, lambe_turah

\begin{abstract}
The latest news about the celebrities can not only be obtained from television infotainment only, but also through gossip accounts in social media. One of them in Instagram account @ lambe_turah. This account is very profitable for business because it can be a media promotion of various products. But by revealing the privacy of people without thinking about the implications and reactions of society because it becomes a problem. Until here hegemony (power) as a social media seems to dominate this phenomenon. Therefore, the purpose of this study is to get an overview of the economic, social and political hegemony of social media on the @lambe_turahgossip account. This research method using literature study. The results conclude that the economic strength of @ lambe_turah can be seen from the messages distributed simultaneously, when and where it can be accepted by its followers consisting of various audiences' class. With the number of millions followers, @lambe_turah enter the line of endorsement programs that generate economic benefits. Political hegemony@_lambe_turah can be seen freely they post any news about the celebrities either the positive or negative. This unlimited power has made@lambe_turah several times having problems with a number of artists especially if the news is negative. While the cultural hegemony in @ lambe_turah is symmetrically illustrated by the many postings that are like and commented on indicate that netizen's attention is very high. @lambe_turah also has a major influence in the formation of public opinion.
\end{abstract}

Keywords: hegemony, social media, gossip account, instagram, lambe_turah 


\section{PENDAHULUAN}

Saat ini berita terbaru tentang para selebritis tidak hanya diperoleh dari tayangan infotainment di televisi saja, tapi juga melalui akun gosip di media sosial. Khusus di Indonesia, akun gosip memiliki pengikut hingga jutaan followers seperti akun Lambe Turah, Lambenyinyir, Makrumpita, Jenk Kellin, Instanyinyir dan lain sebagainya. Beberapa diantaranya kini menjadi acuan informasi, isu dan gosip selebritis atau orang-orang terkenal lainnya.

Media sosial banyak dimanfaatkan sebagai akun gosip, karena tingginya pengguna media sosial di Indonesia. Hasil penelitian yang dilakukan We Are Social, menyebutkan bahwa rata-rata orang Indonesia menghabiskan 3 jam 23 menit sehari untuk mengakses media sosial. Dari total populasi Indonesia sebanyak 265,4 juta jiwa, pengguna aktif media sosial mencapai 130 juta dengan penetrasi 49 persen (Pertiwi, 2018).

Salah satu media sosial yang banyak digunakan adalah Instagram yang praktis untuk berbagai foto dan video kemudian dapat dikomentari dan di-like oleh para followers. Apalagi dengan media sosial yang sifatnya lebih real time dan cepat menjadikan Instagram paling efektif dalam penyebaran berbagai informasi termasuk berita gosip.

Lambe Turah merupakan salah satu akun Instagram dengan jumlah followers (lebih dari 4.4 juta orang/Januari 2018). Akun ini juga memiliki akun imitasi yang paling banyak. Salah satu keunggulan akun ini karena selalu menyebarkan informasi tentang selebritis paling cepat dengan gaya bahasa dalam caption-caption-nya yang khas sehingga banyak diminati oleh netizen. Berita yang disebarkan oleh @lambe_turah merupakan salah satu komoditi yang paling banyak diminati hampir semua kalangan dan berbeda dibanding yang infotainment di televisi. Keunggulan akun inilah yang membuatnya dari sisi bisnis menguntungkan. Karena memiliki followers yang banyak sehingga menjadi modal utama untuk promosi produk atau jasa di akun ini.

Namun disisi lain permasalahan timbul antara lain berita-berita yang disebarkan belum tentu semua benar. Meskipun sifat beritanya terkini, namun karena dikomentari oleh para followers justru menjadi ajang gibah, ujaran kebencian dan kadang berujung dengan pertengkaran baik antara selebritis yang bersangkutan dengan netizen atau para pendukung maupun haters (pembenci) selebriti.

Fenomena ini memunculkan perubahan perilaku pengguna internet yang makin lama makin menjadi sebuah kebiasan yang tidak lagi disadari sebagai sesuai yang tidak etis. Akun-akun gosip ini semata-mata hanya mementingkan keuntungan belaka dengan menguak privasi orang tanpa memikirkan implikasi dan reaksi masyarakat akibat hal tersebut. Hingga disini hegemoni atau kekuatan sebagai media sosial kelihatan mendominasi fenomena ini.

Hegemoni sendiri menurut Gramsci menekankan penerimaan kelompok yang didominasi terhadap kehadiran kelompok dominan. Hegemoni memiliki berbagai kekuatan untuk mempengaruhi masyarakat. Salah satu bentuk kekuatan hegemoni adalah adanya kemampuan untuk menciptakan cara berpikir atau wacana tertentu yang dominan, dianggap benar sehingga masyarakat meyakini wacana tersebut sebagai sesuatu yang benar juga sebaliknya sebagai sesuatu yang salah atau menyimpang.

Media dapat menjadi alat untuk menyebarkan wacana yang dipandang dominan tersebut. Wacana itu disebarkan dan berusaha untuk diresapkan ke dalam 
benak masyarakat sehingga menjadi konsensus bersama. Praktik hegemoni berlaku juga di media sosial yang kini banyak digunakan masyarakat. Hegemoni media sosial dapat dipahami sebagai pengaruh, dominasi dan kekuasaan teknologi berbasis internet yang digunakan sebagai alat interaktif atau pertukaran informasi untuk mencapai suatu kepentingan.

Berdasarkan latar belakang tersebut di atas, maka rumusan masalah dalam penelitian ini adalah bagaimana hegemoni media sosial pada akun gosip @lambe_turah di Instragam? Tujuan dari penelitian ini adalah untuk mendapatkan gambaran tentang hegemoni media sosial pada akun gosip @lambe_turah di Instragam.

\section{LANDASAN TEORI}

Penelitian-penelitian tentang hegemoni di media sosial pernah dilakukan sebelumnya. Salah satunya berjudul "Analisis Wacana Kritis: Hegemoni Media Sosial Twitter Mengenai Isu-Isu Nasional di Indonesia dan Implikasinya pada Mata Kuliah Analisis Wacana di Perguruan Tinggi Analisis Wacana Kritis" yang dilakukan oleh Susanti (2015). Penelitian ini bertujuan mengkaji munculnya hegemoni berdasarkan analisis teks yang terkait dengan representasi, relasi, identitas, dan transformasi terhadap isu-isu nasional yang menjadi trending topic di Twitter. Selain itu penelitian ini bertujuan membahas praktik wacana Twitter mempengaruhi pekerja media dalam memproduksi berita dan untuk melihat implikasi penelitian terhadap pembelajaran analisis wacana. Metode penelitian ini menggunakan metode kualitatif. Penelitian ini menemukan bahwa pejabat-pejabat pemerintah Indonesia mulai menggunakan Twitter sebagai wadah untuk menyampaikan pesan dan sebagai sarana komunikasi dengan rakyatnya. Mereka memilih menjangkau Twitter lebih dahulu dari pada media massa. Media massa menjadikan Twitter sebagai sumber inspirasi dimana banyak tokoh dan pengguna awam yang pendapatnya layak dikutip dan dijadikan bahan penulisan berita. Media massa juga mempublikasikan dan mendistribusikan berita-berita tersebut melalui Twitter dengan harapan mendapatkan umpan balik dan ditanggapi oleh para pengguna Twitter, yang kemudian dijadikan bahan penulisan berikutnya. Di sinilah terlihat kuatnya hegemoni Twitter.

Penelitian lain berjudul "Hegemoni Berpacaran di Facebook" yang dilakukan oleh Falihah dan Hasby (2015). Penelitian ini menggambarkan bahwa Facebook merupakan salah satu bentuk dari perkembangan teknologi informasi dan komunikasi yang populer dan digandrungi masyarakat, tidak terkecuali pada publikasi hubungan asmara. Perkembangan tersebut jugalah yang menjadikan adanya sebuah praktek kekuasaan dan penundukan pada sebuah hubungan asmara di dunia virtual. Penelitian ini menggunakan teori hegemoni Antonio Gramsci sebagai pisau analisisnya. Metode yang digunakan adalah kualitatif dengan pendekatan semiotika. Pendekatan ini digunakan dalam merepresentasikan dan menafsirkan makna yang tersirat pada status, komentar, like dan simbol emoticon yang dituliskan facebookers. Hasil penelitian menunjukkan bahwa pemegang kendali kekuasaan dan penundukan tidak hanya dilakukan oleh kaum laki-laki, tetapi juga perempuan. Sedangkan pola-pola penundukan yang dilakukan adalah dengan hegemoni moral dan intelektual. Hegemoni moral berkaitan dengan profil diri, ungkapan perhatian, pengakuan diri dan klaim-klaim agama. Sedangkan hegemoni intelektual berkaitan dengan kata-kata bijak, 
pengetahuan dan bahasa akademis dan penilaian pasangan secara nyata. Pola tersebut kemudian melahirkan realitas virtual hubungan asmara yang tidak sekedar mainmain.

"The Ambiguous Power of Social Media: Hegemony or Resistance?" merupakan judul penelitan yang dilakukan Olubunmi (2015). Penelitian ini menggambarkan bahwa perkembangan media sosial menunjukkan efektivitasnya sebagai alat yang manjur dan benar-benar memobilisasi jaringan. Warga biasa mengandalkan kekuatan media sosial untuk memobilisasi dan melawan pemerintah yang sedang berkuasa di seluruh dunia. Penggunaan media sosial sebagai alat untuk perlawanan atau hegemoni dalam beberapa tahun terakhir telah membawa isu tersebut ke kekuatan media sosial menjadi yang terdepan dalam perdebatan akademis. Karena itu menjadi keharusan mengeksplorasi sifat ganda dari media sosial untuk menentukan dampaknya terhadap masyarakat. Ini akan menambah pengetahuan tentang media sosial sebagai alat yang benar untuk perlawanan dan hegemoni.

Penelitian-penelitian yang dipaparkan di atas memang khusus membahas tentang hegemoni di media sosial, namun dengan subjek penelitian tentang isu-isu nasional di Twitter, kekuasaan relasi dalam berhubungan (berpacaran) di Facebook dan hegemoni warganet yang menggunakan media sosial untuk memobilisasi jaringan untuk melawan pemerintah. Perbedaan penelitian-penelitian sebelumnya dengan penelitian ini adalah terletak pada media dan subjeknya. Pada penelitian ini yang diteliti adalah media sosial Instagram dan subjeknya adalah akun gosip @lambe_turah. Penelitian serupa belum pernah dilakukan sebelumnya, karena itu dianggap penting untuk melakukan penelitian ini.

Hegemoni atau egemonia (dari bahasa Yunani) yang berarti penguasa atau pemimpin. Secara ringkas, pengertian hegemoni adalah bentuk penguasaan terhadap kelompok tertentu dengan menggunakan kepemimpinan intelektual dan moral secara konsensus. Artinya, kelompokkelompok yang terhegemoni menyepakati nilai-nilai ideologis penguasa. Hegemoni menurut Gramsci (1971) menekankan penerimaan kelompok yang didominasi terhadap kehadiran kelompok dominan berlangsung dalam suatu proses yang damai, tanpa tindakan kekerasan. Hegemoni memiliki berbagai kekuatan untuk memengaruhi masyarakat. Salah satu bentuk kekuatan hegemoni adalah adanya kemampuan untuk menciptakan cara berpikir atau wacana tertentu yang dominan, dianggap benar sehingga masyarakat meyakini wacana tersebut sebagai sesuatu yang benar. Sementara itu hegemoni juga dapat membuat wacana lain dianggap sebagai sesuatu yang salah atau menyimpang.

Media dapat menjadi alat untuk menyebarkan wacana yang dipandang dominan tersebut. Saat ini media massa banyak digunakan sebagai alat untuk menyebarluaskan gagasan tertentu yang mendukung dan memperkuat kekuasaan kelompok tertentu sehingga diterima secara luas oleh masyarakat menjadi sebuah ideologi (Gramsci, 1971),

Praktik hegemoni juga berlaku di media sosial yang kini banyak digunakan oleh masyarakat dunia termasuk di Indonesia. Media sosial merupakan teknologi yang berbasis internet, memungkinkan konten interaktif dibuat, melakukan pengabungan dan kolaborasi, dan pertukaran informasi antara para penggunanya (Van Dijk, 2013). 
Hegemoni media sosial dapat dipahami sebagai pengaruh, dominasi dan kekuasaan teknologi berbasis internet yang digunakan sebagai alat interaktif atau pertukaran informasi untuk mencapai suatu kepentingan. Saat ini penggunaan media sosial tidak lagi dapat dipisahkan dari kehidupan masyarakat. Salah satu bentuk hegemoni di media sosial dapat dilihat dari bergesernya perilaku masyarakat baik dalam memproduksi, mengkonsumsi dan menyebarkan pesan.

Media sosial memiliki karakter jaringan sosial yang terbangun dari struktur sosial yang terbentuk di dalam jaringan atau internet. Namun struktur atau organisasi sosial yang terbentuk di internet berdasarkan jaringan informasi, dasarnya beroperasi berdasarkan teknologi informasi. Jaringan yang terbentuk antar pengguna merupakan jaringan yang dimediasi oleh perangkat teknologi (Castell, 2002). Menurut Fuchs (2014), struktur sosial tidak dapat dilepaskan dari kekuatan atau kekuasaan (hegemoni) yaitu kekuatan ekonomi, politik dan budaya.

Kekuatan ekonomi merupakan penguasaan atau kontrol terhadap nilai guna dan sumber-sumber yang diproduksi, didistribusikan maupun dikonsumsi. Sedangkan struktur kekuatan ekonomi dalam masyarakat modern adalah terdapat kontrol terhadap uang dan kapital. Kekuatan politik adalah keterlibatan dalam keputusan kolektif yang mendeterminasi aspek-aspek kehidupan dari anggota masyarakat suatu komunitas dan sistem sosial tertentu dimana struktur kekuatannya dalam masyarakat modern dapat terlihat dengan adanya kontrol terhadap pemerintah hingga grup masyarakat. Sedangkan kekuatan selanjutnya adalah kekuatan budaya yaitu nilai-nilai moral dan makna yang dianggap sebagai sesuatu yang penting, memiliki reputasi dan bermanfaat dalam masyarakat. Struktur kekuatan budaya dalam masyarakat modern adalah kontrol terhadap struktur yang mendefenisikan makna dan nilai-nilai moral dalam masyarakat (Fuchs, 2014).

Kerangka konseptual yang dapat disusun dalam kajian ini berdasarkan paparan berbagai teori dan konsep di atas adalah sebagai berikut:

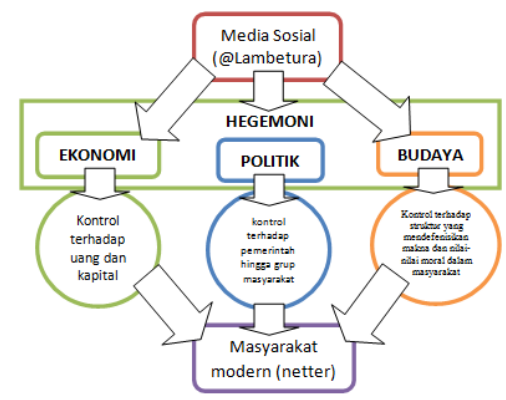

Gambar 1. Kerangka Konseptual (diadaptasi dari Fuchs, 2014)

Kerangka konseptual ini dapat diterangkan sebagai berikut bahwa media sosial dalam hal ini akun gosip @ lambe_turah di Instagram memiliki stuktur sosial yang dalam prakteknya memiliki kekuatan dan kekuasaan (hegemoni) terhadap netizen (masyarakat) yang mengakses akun ini untuk mendapatkan informasi terkini tentang para orang terkenal. Kekuatan dan kekuasaan stuktur sosial ini meliputi tiga aspek yaitu ekonomi, politik dan budaya. Ketiga aspek ini yang dikaji dalam studi ini.

\section{METODE PENELITIAN}

\section{Metode Penelitian}

Penelitian ini menggunakan metode kajian literatur yang dapat mendukung pendekatan analisis teks. Metode kajian literatur adalah serangkaian kegiatan yang berkenaan dengan metode pengumpulan data pustaka, membaca dan mencatat, serta mengelolah bahan penelitian (Zed, 2008). 


\section{Teknik Pengumpulan Data}

Teknik pengumpulan data dalam kajian ini meliputi kajian tentang media sosial, akun Instagram, akun gosip di media sosial, konsep hegemoni, konsep struktur sosial yang meliputi ekonomi, politik dan budaya. Sumber kajian berupa buku referensi, jurnal ilmiah yang dipublikasikan, artikel ilmiah yang berisikan tentang konsep yang diteliti dan referensi pada website yang diakses melalui internet.

Adapun media sosial yang dipilih untuk dikaji adalah Instagram dengan alasan Instagram merupakan salah satu media sosial yang paling banyak digunakan para artis dan orang terkenal lainnya. Disamping itu Instagram merupakan aplikasi berbagi foto yang memungkinkan pengguna mengambil foto, menerapkan filter digital, dan membagikannya ke berbagai layanan jejaring sosial, termasuk milik Instagram sendiri (Frommer, 2010). Sedangkan objek kajian adalah akun gosip @lambe_turah di Instagram, dengan alasan akun ini menjadi ikon tersendiri di dunia hiburan. Karena selalu memberikan gosip hangat para selebiri dan menjadi idola baru di Instagram. Sejak kemunculan di Instagram, Desember 2015, akun@lambe_turah memiliki ribuan follower (Nova, 2017).

\section{Metode Analisis Data}

Teknik analisis data dalam kajian ini adalah secara deskriptif dengan menghubungkan objek penelitian yang dikaji dengan baik secara teoretis, empiris maupun non empiris, sehingga dapat menjawab dengan menjelaskan rumusan masalah yang diajukan. Melakukan perpaduan temuan kajian dengan hasil penelitian sebelumnya dan konsekuensi serta pengembangannya di masa mendatang.

\section{HASIL PENELITIAN DAN PEMBAHASAN}

Akun gosip mulai dikenal sejak media sosial banyak digunakan masyarakat. Salah satu akun gosip di Instagram yang terkenal adalah@lambe_turah. Akun yang memiliki slogan 'Gosip Hanyalah Fakta yang Tertunda' ini menjadi ikon gosip di dunia hiburan. Selain memberikan gosip para selebriti, @lambe_turah menjadi idola baru dan selalu dirujuk untuk mendapatkan informasi terkini mengenai orang terkenal.

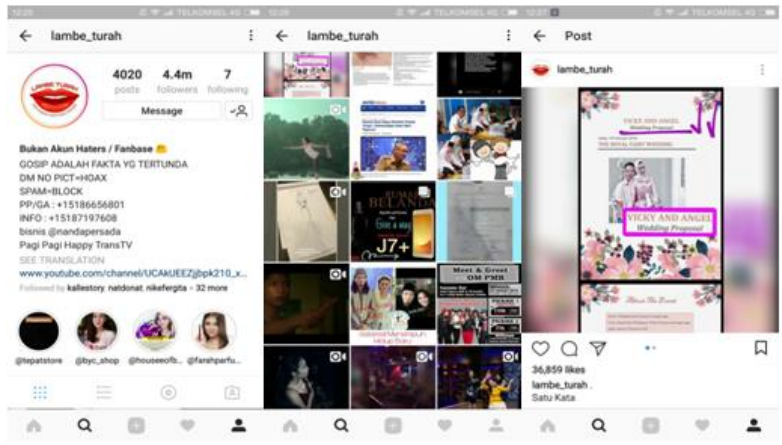

Gambar 2. Akun gosip @lambe_turahdi Instagram (Sumber:https://www.instagram.com/lambe_turah/)

Akun @lambe_turah mulai aktif di Instagram pada Desember 2015. Akun ini kemudian mulai memiliki banyak follower dari tahun ke tahun. Hingga Januari 2018 @lambe_turah sudah memiliki 4,4m followers. Akun dengan nama yang sama (@lambe_turah) di Instagram sebenarnya lebih dari satu. Akun ini seperti mengkloning dirinya menjadi beberapa akun. Sedangkan akun gosip yang sama tetapi dengan nama yang berbeda juga banyak di Instagram seperti lambe_nyiyir, nyonya_gosip, minceu_rumpi, lambe_ramis, nonajadul, lambe_julid dan lain-lain.

\section{Hegemoni Ekonomi @lambe_turah}

Akun@lambe_turah di media sosial merupakan media yang memiliki struktur kepemilikan yang spesifik. Kekuatan ekonominya dapat dilihat dari pesan-pesan 
yang terdistribusi secara bersamaan, kapan dan dimana saja dapat diterima oleh para followers-nya. Pesan berupa gosip maupun fakta tentang orang terkenal di akun ini tersebar secara asimetris ke semua followers yang terdiri dari berbagai kelas atau kelompok khusus khalayak atau biasa disebut private class.

Sejak dibuat tahun 2015 hingga Januari 2018, pesan yang telah diposting dalam @lambe_turah mencapai 4.036 post. Hegemoni ekonomi lainnya yang ada di media ini juga terdistribusi secara simetris, karena media sosial kebanyakan dimiliki oleh pengguna secara kolektif. Ini terlihat dariffollowers @lambe_turah yang mencapai 4,4 m. Sementara feedback followers terhadap setiap postingan (dalam bentuk like dan komentar) di akun ini sangat tinggi. Salah satunya adalah postingan video tentang artis Raisa yang diposting 3 Januari 2018 mencapai 1.787 .715 kali ditonton, dan di like 38.133 kali.

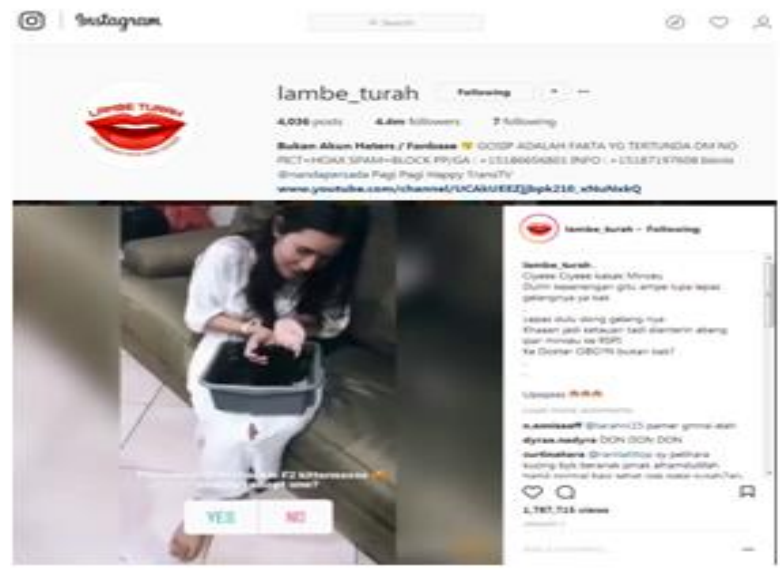

Gambar 3. Akun gosip @lambe_turah di Instagram (Sumber:https://www.instagram.com/p/BddhtAJh2Z G62cvpi34ICeL9j3u8NisqvRffaY0/?takenby=lambe_turah)

Media sosial juga mampu menghasilkan keuntungan ekonomi dengan menjalankan peran penghubung antara dunia produksi dan konsumsi. Akun@lambe_turah juga melakukan kegiatan promosi ini baik dengan memposting sebuah produk seperti sepatu, parfum, pakaian, makanan hingga ajang kegiatan/event) pada timeline-nya maupun pada insta story-nya.

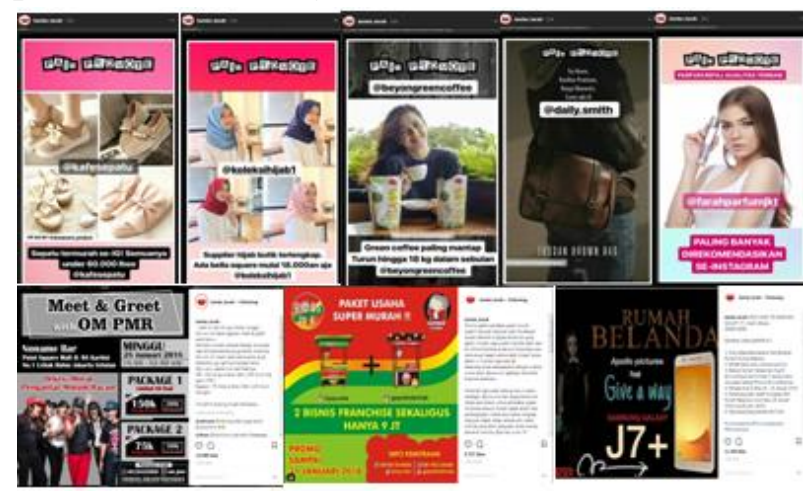

Gambar 4. Promosi berbagai produk dan jasa di akun Instagram @lambe_turah

(Sumber: https://www.instagram.com/lambe_turah/)

Ada juga perusahaan-perusahaan yang melakukan promosi melalui @lambe_turah, salah satunya promosi tentang tempat pariwisata di Labuan Bajo. Hal ini menjadi keuntungan tersendiri bagi perusahaan ini karena postingan tersebut mendapat banyak tanggapan dari followers melalui kolom komentar. Ada yang tertarik dan menandai (tag) ke teman-teman mereka yang lain untuk membaca promosi tersebut, ada yang langsung janjian dengan rekan lain untuk mengikuti paket tour yang ditawarkan dan ada juga ikut memasarkan produk dan jasanya sendiri melalui ruang komentar seperti jasa menjahit baju, investasi usaha dan lain-lain. Hal ini sesuai dengan yang disebut Fuchs (2014) bahwa struktur kekuatan ekonomi dalam masyarakat modern terdapat kontrol terhadap uang dan kapital.

Jumlah pengikut (follower) yang mencapai jutaan, menjadikan @lambe_turah masuk dalam jajaran selebriti Instagram atau selebgram. SociaBuzz atau perusahaan yang mempertemukan antara pengiklan dan selebriti media sosial memberi batasan menjadi selebgram adalah memiliki jumlah followers sebanyak 20.000. Menjadi 
selebgram merupakan pintu masuk ke endorsement atau menjadi akun yang dapat mempromosikan produk atau merek di sebuah akun Instagram (Darmawan, 2017). Menurut Rade (dalam Surono, 2017) kelebihan beriklan melalui selebgram adalah adanya kekuatan pengaruh (kepercayaan) karena memiliki sentuhan personal dengan menggunakan sosok populer di Instagram.

Tarif mengiklankan sebuah produk maupun jasa melalui selebrgam menurut katalog SocialBuzz seperti Chelsea Olivia dengan total followers 13,6 juta sebesar $\mathrm{Rp}$ 20 juta/foto, Olla Ramlan (7,7 followers) sebesar Rp 10 juta/foto, Gilang Dirga dengan 1,7 juta followers sebesar Rp 5,5 juta/foto dan Rp 9 juta/video. Sedangkan untuk akun@lambe_turah, salah satu adminnya tidak mau menyebutkan bayaran yang mereka terima untuk endorsement (Surono, 2017).

"Yang pasti cukup untuk bantu orang-orang yang membutuhkan. Yang kita posting di Lambe Turah. Semua disumbangin. Sementara donasi yang diberikan oleh para pengikutnya diterima langsung. Admin Lambe Turah langsung mendonasikan dana tersebut ke rekening mereka yang membutuhkan. Jadi kita enggakngitung yang penting mereka ngirim bukti transferan. Kita cek selesai." (Mience dalam Surono, 2017).

\section{Hegemoni Politik @lambe_turah}

Hegemoni politik di media sosial adalah keterlibatan dalam keputusan kolektif yang mendeterminasi aspek-aspek kehidupan dari anggota masyarakat suatu komunitas dan sistem sosial tertentu dimana struktur kekuatannya dalam masyarakat modern dapat terlihat dengan adanya kontrol terhadap pihak lain (Fuchs (2014). Kekuatan politik tidak saja dimiliki pada akun @lambe_turah yang dengan bebas memposting berita apa saja tentang para selebriti. Karena kekuasaan yang tanpa batas inilah beberapa kali akun ini bermasalah dengan sejumlah artis, karena merasa dimuat beritanya tanpa izin apalagi jika berita yang diposting tersebut adalah berita negatif. Kebanyakan berita yang diposting di akun ini, juga merupakan hasil foto atau video yang diambil secara diam-diam tanpa sepengetahuan yang diberitakan dengan caption awal: "Dengan kekuatan hengpong jadul cekrek cekrek aplot."

Contoh kasus postingan pada gambar 5, akun artis bernama jennifercoppenreal20 dalam instastory-nya merasa keberatan dengan penyebaran video kekerasan yang melibatkan dirinya oleh akun@lambe_turah.
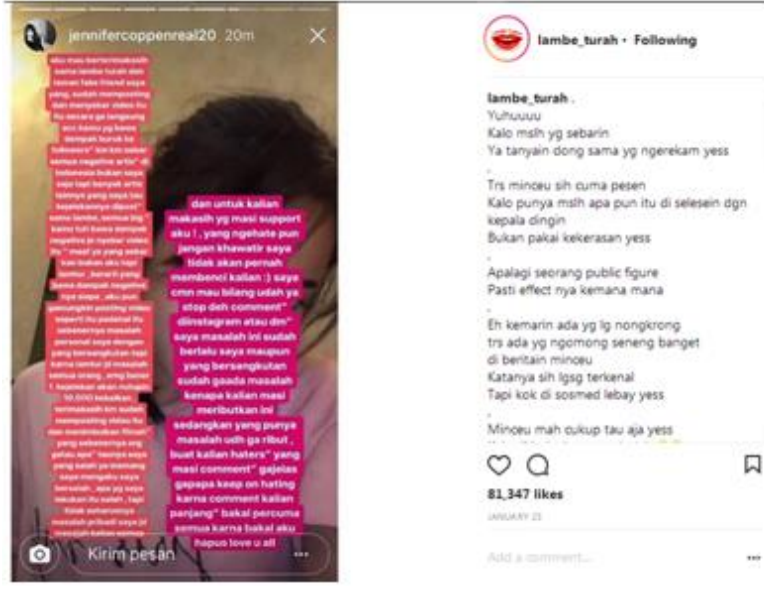

Gambar 5. Hegemoni politik dalam akun @ lambe_tura

(Sumber:https://www.instagram.com/p/BeSpi TkhTz8ji9HrktMwer0QC_x02Ym25b2ntg0/?takenby=lambe_turah)

Menurut Jennifer penyebaran video tersebut memberi dampak buruk bagi followers-nya, dan seharusnya masalah pribadinya bukan menjadi konsumsi publik. Namun akun@lambe_turah dalam postingannya justru membela diri:

lambe turah.Yиһииии Kalo mslh yg sebarin Ya tanyain dong sama yg ngerekam yess.Trs minceu sih cuma pesen Kalo punya mslh apa pun itu di selesein dgn kepala dingin Bukan pakai kekerasan yess. Apalagi seorang public figure Pasti effect nya kemana mana. Eh kemarin ada yg lg nongkrong trs ada yg ngomong seneng banget di beritain minceu. Katanya sih lgsg terkenal Tapi kok di sosmed 
lebay yess Minceu mah cukup tau aja yess Kalo di buka lgsg pecah dah (@lambe_turah, 2017).

Pembelaan @lambe_turah ini banyak mendapat dukungan dari para netizen dalam komentar-komentar mereka namun ada juga yang mendukung Jennifer ada juga yang bersikap lebih netral.

Ifyou Nggak usah munafik. Pake nyalahnyalahin lamtur, tapi lo-lo sendiri masih mampir ke accountnya!

mhiameonk Lagian Lambeturah Secara Gak Langsung Ini mah Ngrusah Hidup Tiap orang pribadi. kasihan tau. Lambeturan Nyari Hidup Diatas Penderitaan orang Lain. Banyak Orang Hancur Hubungannya Karna Lambe Juga.

tuffhijabIntinya $\mathrm{km}$ tu sok artis atau siapalah padahal juga engga terkennal tapi uda sok2 labrak2 MAIN TANGAN segala. Bangga jadi PREMAN YA? Hahahhaaha $\square$ siapa tu namanya je je siapa gtu vanzava07 Haiiii Lambe Turah @lambe_turah aku heran... kepuasan seperti apa yg sebenarnya kamu cari dan kamu dapat dengan memposting postingan orang spt ini? Seperti ga ada kerjaan aja siy Lambe Turah, kamu merasa orang yg paling sempurna ya Lambe $\square \square \square$... membawa postingan orang ke khalayak banyak untuk diejek2? Seperti kamu sendiri ga punya kekurangan $\square \square$

Sebenarnya tidak saja berita negatif yang diposting oleh akun@lambe_turah, namun tidak sedikit juga postinganpostingan positif tentang para orang terkenal yang dapat memberikan inspirasi bagi netizen. Sampai disini dapat dikatakan bahwa inilah hegemoni politik di media sosial. Kekuatan para aktor yang terlibat di dalamnya baik pemilik akun @lambe_turah, orang diberitakan hingga followersnya memiliki keterlibatan dalam keputusan kolektif baik untuk memposting, membalas postingan, memberi komentar baik positif maupun negatif.
Inilah yang disebut Fuchs (2014) sebagai sebuah sistem sosial maya namun struktur kekuatannya terletak pada kontrol terhadap pihak lain. Media sosial menurut Fuchs (2014) memiliki struktur keputusan yang sangat spesifik. Kekuatan politik untuk @lambe_turah terdistribusi secara asimetris dimana kelas atau kelompok khusus memiliki kekuatan untuk memutuskan. Namun kekuatan di media sosial juga terdistribusi secara simetris dimana setiap pengguna memiliki peluang terlibat dalam pengambilan keputusan.

\section{Hegemoni Budaya @lambe_turah}

Fuchs (2014) mengatakan hegemoni atau kekuatan budaya merupakan nilai-nilai moral dan makna yang dianggap sebagai sesuatu yang penting, memiliki reputasi dan bermanfaat dalam masyarakat. Struktur kekuatan budaya dalam masyarakat modern adalah kontrol terhadap struktur yang mendefenisikan makna dan nilai-nilai moral dalam masyarakat.

Kekuatan budaya dalam kasus akun gosip @lambe_turah, secara simetris tergambar dari setiap aktor yang terlibat di dalamnya mulai dari admin @lambe_turah, orang terkenal yang diberitakan hingga para netizen yang menjadi followers yang saling memberikan perhatian satu sama lainnya. Dan secara simetris setiap aktor yang terlibat ini pula memiliki peluang yang sama untuk hadir dan diperhatikan.

Seperti postingan pada gambar 6 tentang artis Dinda Kirana yang sedang makan dengan seorang pria bule. Postingan ini kemudian diberi keterangan (caption):

Mbak dinda kirana \& babang bule nya tercyduk hengpon jadul shay. Ngakunya sih baru sekedar temen yess. Ahhh minceu mah cuma mikir positip. Namanya pacaran berawal dari temenan dulu yess. Hayoo ada gak diantara 
bala2 minceu Yang pertama ketemu langsung pacaran hahaha.

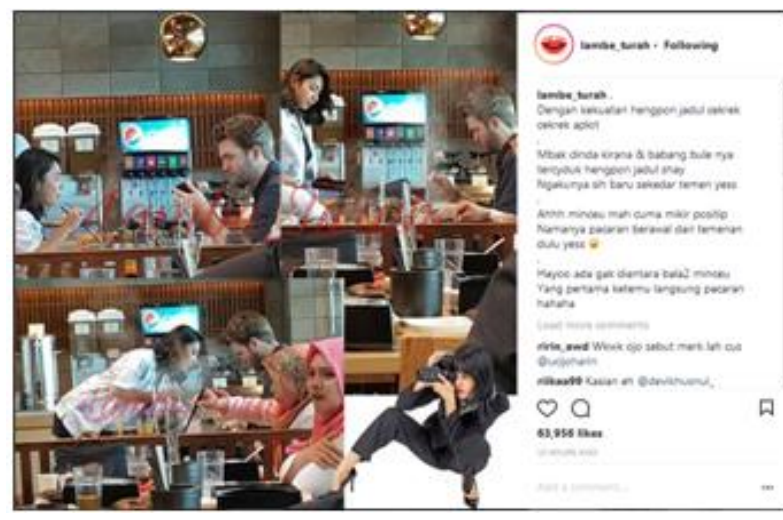

Gambar 6. Hegemoni budaya dalam akun @lambe_turah

(Sumber:https://www.instagram.com/p/Bep6s_Gh8JE OQfB KxMLb9CQryRznniU2y1neI0/?takenby=lambe_turah)

Postingan ini diberikan like oleh netizen sebanyak 63,957 likes dikomentari sebanyak 1098 kali. Ini menandakan bahwa perhatian netizen terhadap berita ini cukup tinggi. Artinya kekuatan budaya terjadi disini. Akun @lambe_turah menganggap apa yang diposting ini penting diketahui oleh netizen, meski tidak semua netizen mengenal dengan baik sang artis, namun antusiasme untuk memberikan like dan komentar cukup besar. Dari komentar-komentar yang ada juga, tidak sedikit follower saling membalas komen untuk bertanya, menjawab pertanyaan atau sekedar menimpali komentar lainnya, termasuk admin lambetura. Meski aktor-aktor yang terlibat di dalamnya tidak saling mengenal secara lagsung sebelumnya. Inilah yang disebut oleh Fuchs (2014), media sosial memiliki hegemoni atau kekuatan budaya karena penggunanya saling memberikan perhatian maupun memaknai kehadiran pengguna lainnya dan setiap pengguna memiliki peluang yang sama untuk hadir dan diperhatikan.
Akun@lambe_turah memang memiliki kekhasan tersendiri jika ditinjau dari hegemoninya di media sosial. Admin akun ini mampu memberikan suguhan kepada netizen tentang sesuatu yang belum pernah diketahui oleh publik. Beberapa kasus selebritas terkenal malah dengan sengaja dibuka cerita masa lalu mereka dengan vulgar. Banyak pihak yang merasa terganggu dengan aksi akun ini, terutama yang menjadi objek dari berita. Tetapi banyak juga yang merasa terhibur dengan mengikuti beritaberita dari akun ini.

Hingga kini, akun @lambe_turah dianggap akun anonim karena tidak diketahui secara pasti orang yang berada dibalik akun ini, meski secara jelas-jelas akun ini juga menerima endorsement sejumlah produk. Beberapa kali akun ini dilaporkan ke polisi atas dugaan pencemaran nama baik diantaranya ketika kasus Mario Teguh versus anaknya mencuat dan diberitakan oleh akun@lambe_turah. Akun ini kemudian menghilang sementara dari Instagram. Polisi kesulitan mengungkap sosok-sosok di balik akun@lambe_turah, sehingga gugatan keluarga Mario Teguh tidak diteruskan. Akun ini kembali beraktivitas beberapa saat setelah isu ini mereda. Bahkan menjadi lebih kuat dan memiliki followers yang militan (Wargadiredja, 2017).

Lambe_turah semakin memiliki pengaruh dan kekuatan tersendiri dalam pembentukan opini publik. Apalagi ditambahkan dengan komentar-komentar followers yang cenderung semakin penguatkan opini publik yang terbentuk. Hal ini senada dengan hasil penelitian yang dilakukan oleh Juditha (2014) tentang opini publik di Twitter yang menyebutkan bahwa opini-opini pribadi di media sosial dengan cepat saling mempengaruhi satu sama lain sehingga dapat membentuk satu kesamaan 
opini yang menggiring opini pribadi menjadi opini publik.

Apalagi caption yang ditulis Minceu (sebutan admin Lambe Turah) dinilai unik, lucu, dan menghibur. Hal ini kemudian menciptakan tren bahasa gaul tersendiri seperti sesebapak, mamam batako, lanjut ngunyah serbuk gergaji, dan lain-lain (Nova, 2017). Kepada majalah Nova (2017), @lambe_turah mengaku mendapatkan berita mulai mencari-cari gosip sendiri lewat penelusuran mendalam di media sosial dan Google, juga banyak mendapat informasi dari followers lewat direct message.

"Tujuannya memang untuk menghibur saja karena kita tahu bukti yang Minceu posting itu aja udahnyakitin hahaha.Jad i gimana caranya supaya si artis ini enggak terlalu baper, ya Minceu mainin aja di caption. Tapi yang nyakitin biasanya justru komentarkomentar followernya. Kadang kalau komennya sudah berlebihan, Minceu hapus-hapusin, tapi, ya, kadang tetap ada yang kelewat." (Nova, 2017).

Kekuasaan para followers di media sosial tidak diragukan lagi. Komentarkomentar penuh kebencian dalam akun @lambe_turah misalnya yang dilakukan oleh netizen tidak dapat dihindari. Jika ada artis yang sedang sakit diberitakan oleh @lambe_turah, banyak yang komentar mendoakan kesembuhan si artis tapi banyak juga yang menghujat karena penampilan sang artis yang tidak tertutup. Dibagian lain, komentar-komentar yang menghina fisik, gaya berpakaian, keluarga hingga masa lalu si artis juga terjadi. Netizen dengan berbagai latar belakang sosial, usia, pekerjaan, pendidikan berbaur menjadi satu dalam akun @lambe_turah dan dengan bebas berkomentar dan berujar kebencian. Namun tidak semua komentar yang ada menjelekjelekkan dan menghujat ada juga yang netral dan konstruktif.
Apa yang tergambar ini sejalan dengan hasil penelitian yang dilakukan oleh Juditha (2017) tentang "Hatespeech di Media Online" bahwa kini orang begitu spontan mengungkapkan apa yang dirasakan mulai secara halus hingga frontal dan tidak terkendali. Kini yang kerap terjadi orang tidak lagi bisa menahan diri dan menyerang orang lain tanpa ampun. Bahkan emosi pengguna internet lebih mudah tersulut hanya dengan membaca kata-kata di media sosial yang kemudian dibalas dengan katakata dan kalimat-kalimat yang juga menghina, melecehkan dan sama-sama menyakitkan. Hal ini merupakan bagian dari hegemoni di media sosial.

Seperti yang disebutkan sebelumnya bahwa kekuasaan dan pengaruh di media sosial tidak dapat dilepaskan dari hegemoni ekonomi, politik dan budaya. Apa yang tergambar pada akun lambeturah sebagai akun gosip hanya salah satu contoh produk media yang semakin praktis. Mc Quails (2000) mengatakan bahwa teknologi berkaitan dengan produk media kini berkembang pesat menghasilkan produk media yang praktis. Hal ini menyebabkan Industri media termasuk media sosial bukan lagi menjadi institusi sosial melainkan sebagai institusi ekonomi. Media sosial mampu merepresentasikan diri sebagai ruang publik yang utama dan turut menentukan dinamika sosial, politik, dan budaya.

Sudibyo (2004) juga berpendapat sama, bahwa media sosial mampu menghasilkan surplus ekonomi dengan menjalankan peran penghubung antara dunia produksi dan konsumsi. Disamping itu media sosial tidak hanya memiliki fungsi sosial dan ekonomi, tetapi juga menjalankan fungsi ideologis. Melalui pola kepemilikan dan melalui produk-produk yang disajikan, media sosial adalah perangkat ideologis yang melanggengkan dominasi kelas pemilik 
media itu sendiri (@lambe_turah) terhadap publik maya.

Hegemoni menurut Gramsci (1971) yang tergambar disini bahwa akun lambeturah mampu memiliki berbagai kekuatan untuk mempengaruhi masyarakat (netizen atau followers-nya). Salah satu bentuk kekuatan hegemoni @lambe_turah adalah kemampuan untuk menciptakan cara berpikir atau wacana tertentu yang dominan, dianggap benar sehingga masyarakat meyakini wacana tersebut sebagai sesuatu yang benar. Sementara itu hegemoni juga dapat membuat wacana lain dianggap sebagai sesuatu yang salah atau menyimpang.

Isi pesan yang disampaikan oleh akun @lambe_turah baik negatif maupun positif, baik buruk maupun elok, tetap dianggap sebagai suatu kebenaran meski pun awalnya berita tersebut hanya rumor semata. Disadari atau tidak meski diakui oleh admin @lambe_turah sebagai media hiburan belaka, namun tidak dipungkiri akun ini digunakan sebagai alat untuk menyebarluaskan gagasan tertentu yang mendukung dan memperkuat kekuasaan kelompok tertentu sehingga diterima secara luas oleh masyarakat menjadi sebuah ideologi. Misalnya seperti kehidupan artis yang buruk maupun sebaliknya.

Potret selebritis atau orang terkenal yang ikut diposting melalui akun @lambe_turah menggambarkan suatu kelas sosial dominan untuk memproyeksikan cara mereka dalam memandang dunia dan para netizen menikmati dan menyukai keberadaan kelas dominan tersebut. Hal inilah yang disebut Gramsci (1971) kelompok dominan bukan semata-mata bisa mempertahankan dominasi karena kekuasaan, tetapi karena masyarakat sendiri yang mengizinkan.

Melalui media sosial hegemoni dilakukan, dimana secara perlahan-lahan memperkenalkan, membentuk, dan menanamkan pandangan tertentu dalam bentuk pesan, berita gambar, video dan sebagainya kepada publik (netizen). Hegemoni ini tidak hanya ada pada aktoraktor semata namun pada perangkat teknologi informasi dan komunikasi juga yang Van Dijk (2013) menyebutnya sebagai pengaruh, dominasi dan kekuasaan teknologi berbasis internet yang digunakan sebagai alat interaktif atau pertukaran informasi untuk mencapai suatu kepentingan.

\section{PENUTUP}

\section{Kesimpulan}

Hasil penelitian menyimpulkan bahwa akun @lambe_turah di Instagram memiliki struktur kepemilikan yang spesifik. Kekuatan ekonominya dapat dilihat dari pesan-pesan yang terdistribusi secara bersamaan, kapan dan dimana saja dapat diterima oleh followers-nya yang terdiri dari berbagai kelas atau kelompok khusus khalayak.

Akun@lambe_turah juga melakukan kegiatan promosi ini baik dengan memposting sebuah produk seperti sepatu, parfum, pakaian, makanan hingga ajang kegiatan pada timelinenya maupun pada insta storynya. Hal ini menghasilkan keuntungan ekonomi dengan berperan sebagai penghubung antara dunia produksi dan konsumsi. Jumlah pengikut (follower) yang mencapai jutaan menjadikan @ lambe_turah masuk dalam jajaran selebriti Instagram (selebgram) yang menjadi pintu gerbang masuk ke dunia endorsement atau menjadi akun yang dapat mempromosikan produk atau merek disebuah akun Instagram.

Hegemoni atau kekuatan politik juga dimiliki oleh akun @lambe_turah yang dengan bebas memposting berita apa saja tentang para selebriti baik sisi positif 
maupun negatifnya. Kekuasaan yang tanpa batas inilah menjadikan @lambe_turah beberapa kali memiliki masalah dengan sejumlah artis, karena merasa dimuat beritanya tanpa izin apalagi jika berita tersebut negatif. Hegemoni politik para aktor yang terlibat di dalamnya baik pemilik akun @lambe_turah, orang diberitakan hingga followers-nya memiliki keterlibatan dalam keputusan kolektif baik untuk memposting, membalas postingan, memberi komentar positif maupun negatif.

Sama dengan hegemoni politik, untuk hegemoni budaya dalam akun gosip @lambe_turah, secara simetris tergambar dari setiap aktor yang terlibat di dalamnya (admin, selebritas yang diberitakan followers) saling memberikan perhatian satu sama lainnya serta secara simetris memiliki peluang yang sama untuk hadir dan diperhatikan. Banyaknya postingan yang diberikan like dan dikomentari oleh netizen menandakan bahwa perhatian netizen sangat tinggi. Artinya kekuatan budaya terjadi disini. Admin akun ini mampu memberikan suguhan kepada netizen tentang sesuatu yang belum pernah diketahui oleh publik. Lambe_turah memiliki pengaruh dan kekuatan tersendiri dalam pembentukan opini publik. Apalagi ditambahkan dengan komentar-komentar followers yang cenderung semakin penguatkan opini publik yang terbentuk. Kekuasaan para followers di akun@lambe_turah dapat dilihat dari komentar-komentar penuh kebencian mereka terhadap seorang artis misalnya, namun ada juga yang netral dan konstruktif. Akun @lambe_turah mampu memiliki kekuatan untuk mempengaruhi netizen dengan menciptakan cara berpikir atau wacana tertentu yang dominan, dianggap benar sehingga masyarakat meyakini wacana tersebut sebagai sesuatu yang benar.

\section{Saran}

Rekomendasi dari kajian ini adalah pemerintah menetapkan suatu aturan yang berhubungan dengan menggunaan media sosial seperti akun gosip @lambe_turah hingga ada aturan dan batasan yang jelas terhadap akun-akun sejenis dalam menyebarkan pesan sehingga tidak merugikan masyarakat. Akun-akun sejenis tidak semata mengandalkan keuntungan ekonomi dari aktifitasnya dalam menyebarkan berita gosip namun tetap menjunjung tinggi etika dalam bermedia sosial. Para netizen juga seharusnya semakin bijak dalam menanggapi (memberikan komentar) dalam setiap postingan tidak saja pada akun gosip seperti ini namun di semua ruang komentar yang ada di media sosial, sehingga tidak bermasalah di kemudian hari. Penelitian lanjutan tentang hegemoni media sosial dapat dilanjutkan dengan objek penelitian lainnya.

\section{UCAPAN TERIMA KASIH}

Terima kasih saya ucapkan kepada beberapa pihak yang membantu dalam proses penyelesaian karya tulis ilmiah ini. Baik pihak yang menyediakan sarana dan prasarana, tempat berdiskusi dan pihak yang telah banyak memberikan bahan literatur maupun data-data yang dibutuhkan dalam proses penyusunan karta tulis ini.

\section{DAFTAR PUSTAKA}

Castell, Manuel. (2002). The Internet and the Network Society. In B. Wellmann \& C. Haythornhwaite (Eds.) The Internet in Everyday Life. Malden, MA: Blackwell Publishing Ltd.

Darmawan, Budi. (2017). Punya 2,5 Juta Follower, Inilah Perkiraan Biaya Untuk Endorsement Lambe Turah. Diakses dari website: 
http://palembang.tribunnews.com/2017/ 05/05/punya-25-juta-follower-inilahperkiraan-biaya-untuk-endorsementlambe-turah, pada 29 Januari 2018.

Falihah, Isnaini Afriliyah dan Ali Hasby. (2013). Hegemoni Berpacaran Di Facebook. Jurnal Paradigma. Volume 01 Nomor 01 Tahun 2013.

Fuchs,C. (2014). Social Media a Critival Introduction. Los Angeles: Sage Publicatiobs, Ltd.

Frommer, D. (2010). Here's How To Use Instagram. Business Insider.

Gramsci, Antonio (1971). "Introduction". In Hoare, Quentin; Smith, Geoffrey Nowell. Selections from the Prisoncasetell Notebooks. New York: International Publishers. pp. xvii-xcvi. ISBN 0-85315-280-2.

Juditha, Christiany. (2014). Opini Publik Terhadap Kasus KPK Lawan Polisi dalam Media Sosial Twitter. Jurnal Pekommas, Vol. 17 No. 2, Agustus 2014: 61-70 61. hal 137-151.

Juditha, Christiany. (2017). Hatespeech di Media Online: Kasus Pilkada DKI Jakarta 2017. Jurnal Penelitian Komunikasi dan Opini Publik Vol 21, No 2 (2017) hal 137 - 151.

Lambe Turah. (2018). @lambe_turah. Diakses dari website: https://www.instagram.com/lambe_tura h/, pada 15 Januari -5 Februari 2018

Nova. (2017). Terkuak! Ini Profesi 5 Orang Admin Dibalik Tenarnya Akun Lambe Turah di Sosial Media. Diakses dari website:

http://nova.grid.id/Selebriti/Berita-

Aktual/Terkuak-Ini-Profesi-5-Orang-

Admin-Dibalik-Tenarnya-Akun-Lambe-

Turah-Di-Sosial-Media pada 23 Januari 2018.

McQuail, Denis. (2002). Media

Performance: Mass Communication and
The Public Interest. London: Sage Publication.

Olubunmi, Aborisade Philip. (2015). The Ambiguous Power of Social Media: Hegemony or Resistance? Journal New Media and Mass Communication Vol.33, 2015. Diakses dari website: http://webcache.googleusercontent.com/ search?q=cache:93i7wf-

nC9sJ:eprints.abuad.edu.ng/692/1/1921

3-21815-1-

PB.pdf $+\& c d=4 \& h l=e n \& c t=c \operatorname{lnk} \& g l=i d$, pada 11 Januari 2018.

Pertiwi, Wahyunanda Kusuma. (2018). Riset Ungkap Pola Pemakaian Medsos Orang Indonesi. Diakses dari website: https://tekno.kompas.com/read/2018/03/ 01/10340027/riset-ungkap-polapemakaian-medsos-orang-indonesia., pada 10 Juli 2018.

Sudibyo, Agus. (2004). Ekonomi Politik Media Penyiaran. Jogjakarta: LkiS.

Surono, Agus. (2017). Punya 2,5 Juta Follower, Inilah Perkiraan Biaya Untuk Endorsement Lambe Turah. Diakses dari website: http://intisari.grid.id/Techno/Technolog y/Punya-25-Juta-Follower-InilahPerkiraan-Biaya-Untuk-EndorsementLambe-Turah?page $=2$ pada 25 Januari 2018.

Susanti, Elvi. (2017). Analisis Wacana Kritis: Hegemoni Media Sosial Twitter Mengenai Isu-Isu Nasional di Indonesia dan Implikasinya pada Mata Kuliah Analisis Wacana di Perguruan Tinggi. Disertasi Pendidikan Bahasa Indonesia Sekolah Pascasarjana Universitas Pendidikan Indonesia. Diakses dari website:

http://repository.upi.edu/22983/1/D_B.I ND_1006975_Title.pdf, pada 15 Januari 2018. 
Wargadiredja, Arzia Tivany. (2017).

Hegemoni Lambe Turah Atas Dunia

Maya Indonesia. 